\title{
ATP-induced focal adhesion kinase activity is negatively modulated by phospholipase D2 in PC12 cells
}

\author{
Yoe-Sik Bae ${ }^{1}$ and Sung Ho Ryu ${ }^{1,2}$ \\ ${ }^{1}$ Division of Molecular and Life Sciences, Pohang University of \\ Science and Technology, Pohang 790-784, Korea \\ ${ }^{2}$ Corresponding author: Tel, +82-54-279-2292; \\ Fax, +82-54-279-2199; E-mail, sungho@postech.ac.kr
}

Accepted 18 September 2001

Abbreviations: Fak, focal adhesion kinase; PLD, phospholipase D; PA, phosphatidic acid; PC, phosphatidylcholine; DAG, diacylglycerol; PBt, phosphatidylbutanol; PKC, protein kinase C; PAP, phosphatidic acid phosphohydrolase

\begin{abstract}
Extracellular ATP has been known to modulate various cellular responses including mitogenesis, secretion and morphogenic activity in neuronal cells. In the ATP-induced morphogenic activity, focal adhesion kinase(s) such as Fak have been suggested to play a critical role. Binding of ATP to its specific cell surface receptor in PC12 cells induces phospholipase D (PLD) activity. However, the role of PLD on ATP-induced Fak activation in PC12 cells remains unclear. In this study, we investigated the role of PLD on the ATP-induced Fak activation and paxillin phosphorylation using two established cell lines: wild type PLD2- and lipase-inactive mutant PLD2inducible PC12 cells. Stimulation of cells with ATP caused PLD2 activation via classical protein kinase C activation. ATP also induced Fak activation, and paxillin phosphorylation, and were dramatically reduced by wild type PLD2 overexpression but not by lipase-inactive mutant PLD2 overexpression. When the PC12 cells were pretreated with propranolol, a specific inhibitor for phosphatidic acid phosphohydrolase resulting in the accumulation of PA, ATPinduced Fak activation and paxillin phosphorylation were also reduced. We found that inhibition of tyrosine phosphatases by pervanadate completely blocked PLD2-dependent Fak and paxillin dephosphorylation. Taken together, we suggest that PLD2 activity might play a negative role in ATP-induced Fak and paxillin phosphorylation possibly through tyrosine phosphatases.
\end{abstract}

Keywords: Focal adhesion kinase, Phosphatidic acid, Phospholipase D, Paxillin, Tyrosine phosphatase

\section{Introduction}

Purinergic receptors have been reported to play important roles on the regulation of neuronal cell functions (Communi et al., 2000; Di lorio et al., 1998). ATP, a ligand for the receptors modulate various cellular responses such as mitogenic and morphogenic activity in PC12 rat pheochromocytoma cells (Neary et al., 1996; Soltoff et al., 1998; Schindelholz et al., 2000). Stimulation of cells with ATP induces tyrosine phosphorylation of several cytoskeletal proteins and focal adhesion molecules such as focal adhesion kinase (Fak), prolinerich tyrosine kinase (Pyk2), and paxillin (Soltoff et al., 1998; Schindelholz et al., 2000). Since these cytoskeleton-associated proteins have been regarded as important factors for the regulation of neuronal cell functions, the study on the regulatory mechanism for the proteins remains an important issue.

Phospholipase D (PLD) catalyzes the hydrolysis of phosphatidylcholine (PC) into phosphatidic acid (PA) and choline. PA can be further converted to diacylglycerol (DAG) by PA phosphohydrolase (PAP). PLD has been implicated in a broad range of cellular functions including cytoskeletal rearrangement, vesicle trafficking, and mitogenesis in neuronal cells (Frohman et al., 1999; Liscovitch et al., 2000; Glenn et al., 1998). To date, two isozymes of PLD (PLD1 and PLD2) have been cloned in mammalian cells (Exton, 2000). Recently we reported that PLD2 is responsible for ATP-induced PLD activation in PC12 cells (Lee et al., in press). In this study, we investigated the role of PLD2 activity on ATPinduced Fak and paxillin phosphorylation in PC12 cells.

\section{Materials and Methods}

\section{Materials}

$\left[{ }^{3} \mathrm{H}\right]$ Myristic acid (54 Ci/mmol) was purchased from Amersham International (Buckinghamshire, U.K.). Silica gel 60 TLC plates were purchased from Merck (Darmstadt, Germany). GF109203X, Ro-31-8220, PD98059, Gö6976, and rottlerin were purchased from Calbiochem Corp. (San Diego, CA). LY294002 was from Biomol Laboratories, Inc. (Plymouth Meeting, PA). Anti-Fak antibody and anti-paxillin antibody were obtained from Santa Cruz biotechnology, Inc. (Santa Cruz, CA). Anti-phosphotyrosine antibody was from Upstate biotechnology (Lake Placid, NY). Peroxidase-conjugated anti-mouse and antirabbit IgG were purchased from Kirkegaard and Perry Laboratories Inc. (Gaithersburg, MD). 


\section{Cell culture}

Established rat pheochromocytoma PC12 PLD2 Tet-off cells (wild-type PLD2 inducible cells and lipase-inactive mutant PLD2 inducible cells) were cultured at $37^{\circ} \mathrm{C}$ in a humidified $5 \% \mathrm{CO}_{2}$ atmosphere in high-glucose DMEM supplemented with $10 \%$ heat-inactivated equine serum and $5 \%$ heat-inactivated fetal calf serum.

\section{Measurement of phosphatidylbutanol (PBt) formation}

The production of PBt was determined as described in a previous report (Lee et al., 2000). PC12 cells were subcultured in six-well tissue culture plates at $1 \times 10^{6}$ cells/well in the absence or presence of tetracycline $(0.5$ $\mu \mathrm{g} / \mathrm{ml})$. The cells were labeled with $\left[{ }^{3} \mathrm{H}\right]$ myristic acid $(5$ $\mu \mathrm{Ci} / \mathrm{ml}$ ) for $3 \mathrm{~h}$ at $37^{\circ} \mathrm{C}$. The labeled cells were then washed twice with serum-free DMEM and used for PBt formation assay. Previously we showed that stimulation of PC12 cells with agonists for G protein-coupled receptor such as ATP and bradykinin induced maximal PLD activity within $1 \mathrm{~min}$ (Lee et al., 2000; Lee et al., in press). In this study we stimulated $\left[{ }^{3} \mathrm{H}\right]$ myristic acidlabeled PC12 cells with ATP $(500 \mu \mathrm{M})$ for 1 min in the presence of $0.4 \%$ butan-1-ol. After $1 \mathrm{~min}$, the reactions were quenched by addition of $0.5 \mathrm{ml}$ ice-cold methanol followed by aspiration of the medium. After adding $1 \mathrm{ml}$ of chloroform and $0.5 \mathrm{ml}$ of $1 \mathrm{M} \mathrm{NaCl}$, total lipids were extracted by vigorous vortexing. The lower phase obtained after centrifugation at $550 \mathrm{~g}$ for $10 \mathrm{~min}$ was dried under nitrogen gas. The lipids were then solubilized with chloroform: methanol $(95: 5)$, spotted onto silica gel 60 TLC plates, and separated using a solvent containing chloroform: methanol: acetic acid (90:10:10) as described previously (Lee et al., 2000). To determine the amounts of PBt and total lipids, a Fuji BAS-2000 image analyzer (Fuji Film Co., LTD, Japan) was used.

\section{Cell stimulation and immunoprecipitation}

Cultured cells were stimulated with ATP $(500 \mu \mathrm{M})$ for 1 $\mathrm{min}$. Then the cells were solubilized with lysis buffer $(20$ $\mathrm{mM}$ Tris- $\mathrm{HCl}, \mathrm{pH} 7.2,10 \%$ glycerol, $150 \mathrm{mM} \mathrm{NaCl}, 1 \%$ Triton X-100, $1 \mathrm{mM} \mathrm{Na}_{3} \mathrm{VO}_{4}, 50 \mathrm{mM} \mathrm{NaF}$, leupeptin (10 $\mu \mathrm{g} / \mathrm{ml})$, and $1 \mathrm{mM}$ phenylmethylsulfonyl fluoride). Solubilized proteins were harvested by centrifugation at $4^{\circ} \mathrm{C}$ for $5 \mathrm{~min}$ at 20,000 $\mathrm{g}$. For the anti-phospho-tyrosine immunoprecipitation, protein A-Sepharose coupled monoclonal antibodies to anti-phospho-tyrosine (4G10) $(5 \mu \mathrm{g})$ or anti-Fak $(2 \mu \mathrm{g})$ were added to cell lysates $(1 \mathrm{mg})$ at $4^{\circ} \mathrm{C}$ for $4 \mathrm{~h}$. The immune complexes were washed five times with lysis buffer. Immunoprecipitated proteins were released by heating at $95^{\circ} \mathrm{C}$ for $5 \mathrm{~min}$ with Laemmli cooking buffer for immunoblot analysis.

\section{Immunoblot analysis}

Prepared samples were separated on an $8 \%$ SDSPAGE and transferred onto nitrocellulose membrane.
After blocking the membranes with $5 \%$ skim milk in Tris buffered saline (TBS) (10 mM Tris-HCl, pH 8.0; 150 mM $\mathrm{NaCl}$ ) containing $0.05 \%$ Tween 20 , the membranes were incubated for $4 \mathrm{~h}$ with $1 \mu \mathrm{g} / \mathrm{ml}$ of anti-Fak antibodies, anti-phospho-tyrosine antibodies, or anti-paxillin antibodies. Detection was performed with a peroxidase conjugated anti-rabbit (or mouse) IgG secondary antibody and an enhanced chemiluminescence system (Amersham, U.K.).

\section{Results}

\section{ATP stimulates PLD2 activity via classical PKC in PC12 cells}

In PC12 cells, overexpression of wild type or lipaseinactive PLD2 was found to be under the control of an inducible tetracycline-regulated promoter (Lee et al., 2000)

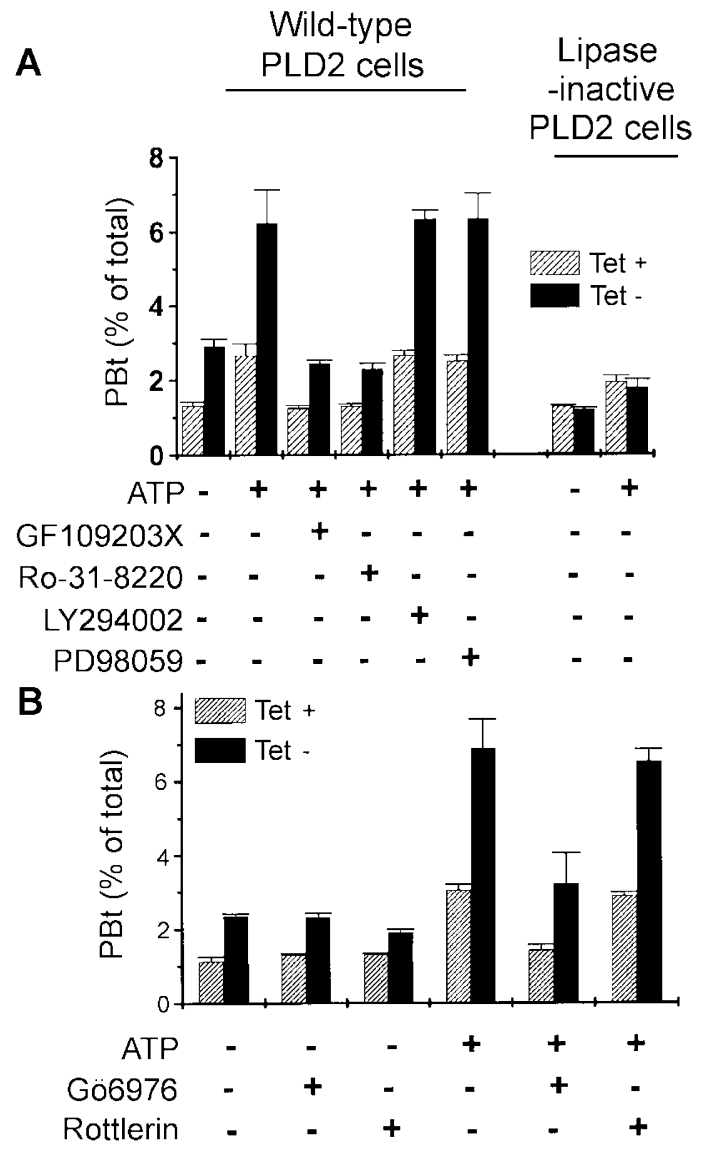

Figure 1. Effect of several inhibitors on ATP-induced PLD2 activation. The PLD2-overexpressing PC12 cells were cultured in the presence or absence of tetracycline $(0.5 \mu \mathrm{g} / \mathrm{ml})$ for $48 \mathrm{~h}$. The cells were labeled with $\left[{ }^{3} \mathrm{H}\right]$ myristic acid $(2 \mu \mathrm{Ci} / \mathrm{ml})$ for $\left.3 \mathrm{~h} .{ }^{3} \mathrm{H}\right]$ myristic acid-labeled PC12 cells were pretreated with GF109203X (5 $\mu \mathrm{M})$, Ro-31-8220 (5 $\mu \mathrm{M})$, LY294002 (50 $\mu \mathrm{M})$, PD98059 $(50 \mu \mathrm{M})(\mathrm{A})$, Gö6976 $(5 \mu \mathrm{M})$, rottlerin $(5 \mu \mathrm{M})$, or vehicle alone $(B)$ for 15 min, and then the cells were stimulated with ATP $(500 \mu \mathrm{M})$ for 1 min in the presence of $0.4 \%$ 1-butanol. The amount of $\left[{ }^{3} \mathrm{H}\right] \mathrm{PBt}$ formed is expressed as percentage of the total labeled lipids. Data are average values \pm SE of triplicate determinations of two independent experiments. 
and ATP stimulated PLD2 activity in PC12 cells (Lee et al., in press). In continuation of purinergic receptor study, here, we have investigated the signaling pathway involved in ATP-induced PLD2 activation. ATP has been reported to activate several signaling molecules including protein kinase $\mathrm{C}$ (PKC), extracellular regulated protein kinases (ERKs), and phosphoinositide-3-kinase (PI3K) that are also known to be involved in agonist-stimulated PLD activation (Kim et al., 1999; Kozawa et al., 1997; Djerdjouri et al., 1999). When PC12 cells were pretreated with inhibitors of each protein prior to ATP stimulation, only PKC inhibitors (GF109203X and Ro-318220) significantly inhibited ATP-induced PLD activity (Figure 1A). To delineate which isoform of $P K C$ is involved in ATP-induced PLD2 activation, we pretreated the cells with PKC isoform specific inhibitors (Gö6976 for classical PKC inhibitor; rottlerin for $\delta$ type PKC inhibitor). As shown in Figure 1B, only Gö6976 but not rottlerin inhibited ATP-induced PLD2 activity. These

A
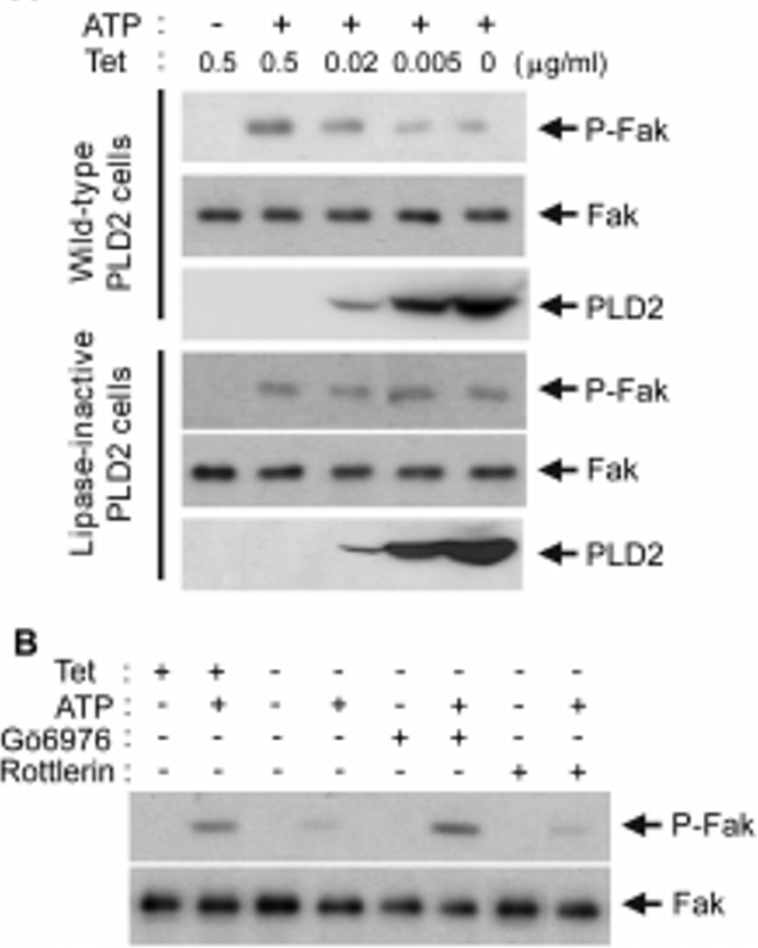

Figure 2. Effect of PLD2 overexpression on ATP-stimulated Fak phosphorylation. The wild-type PLD2 inducible PC12 cells or the lipaseinactive-mutant PLD2 inducible cells were cultured for $48 \mathrm{~h}$ at the indicated concentration of tetracycline (Tet) and then were washed twice with serumfree DMEM. The cells were stimulated with ATP $(500 \mu \mathrm{M})$ for $1 \mathrm{~min}$ and were lysed with lysis buffer (A). PC12 cells were pretreated with Gö6976 (5 $\mu \mathrm{M})$, rottlerin $(5 \mu \mathrm{M})$, or vehicle alone for 15 min prior to ATP $(500 \mu \mathrm{M})$ for 1 min. (B). The extent of Fak phosphorylation was measured through immunoprecipitation with anti-Fak antibody and Western blot analysis with anti-phospho-tyrosine antibody. The amount of proteins used for immunoprecipitation was compared by Western blot analysis with anti-Fak antibody. Data are representative of two independent experiments. results indicate that ATP stimulates PLD2 activity via classical PKC in PC12 cells.

\section{PLD2 activity reduces ATP-stimulated Fak and paxi- Ilin phosphorylation}

Several reports demonstrated that the activation of purinergic receptors by ATP stimulates Fak activity in PC12 cells (Soltoff et al., 1998). To investigate the effect of PLD2 activity on ATP-induced Fak phosphorylation, we measured Fak activity by ATP in two PLD2-inducible (wild type and lipase-inactive mutant PLD2) PC12 cells. As shown in Figure 2A, ATP stimulation induced Fak phosphorylation and such phosphorylation was reduced as the wild type PLD2 expression increased. However, lipase-inactive mutant PLD2 overexpression in PC12 cells did not affect on ATP-induced Fak phosphorylation (Figure 2A). This result indicates that PLD2 activity is required for the reduction of Fak phosphorylation by ATP. When the cells were pretreated with Gö6976 but not rottlerin, PLD2-mediated Fak dephosphorylation was abolished (Figure 2B) suggesting the role of classical PKC in the event. Paxillin, a protein localized in focal adhesion is known as a substrate of Fak (Turner, 2000). Since we found that overexpression of wild type PLD2 attenuated ATP-induced Fak phosphorylation, we ex-

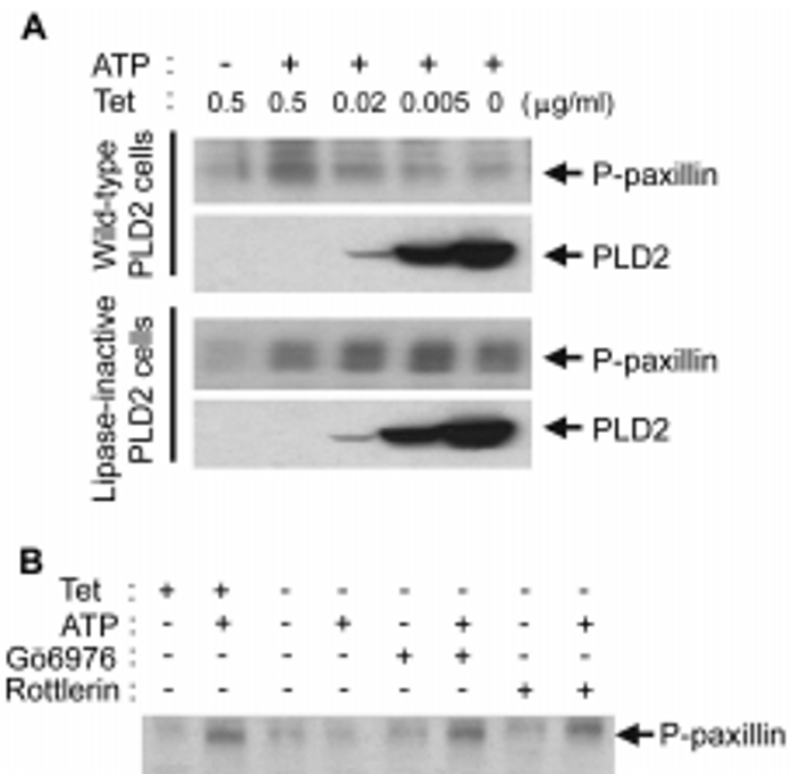

Figure 3. Effect of PLD2 overexpression on ATP-stimulated paxillin phosphorylation. The wild-type PLD2-inducible PC12 cells or the lipaseinactive-mutant PLD2-inducible cells were cultured for $48 \mathrm{~h}$ at the indicated concentration of tetracycline (Tet) and then were washed twice with serumfree DMEM. The cells were stimulated with ATP $(500 \mu \mathrm{M})$ for $1 \mathrm{~min}$ and were lysed with lysis buffer. PC12 cells were pretreated with Gö6976 $(5 \mu \mathrm{M})$, rottlerin $(5 \mu \mathrm{M})$, or vehicle alone for $15 \mathrm{~min}$ prior to ATP $(500 \mu \mathrm{M})$ for $1 \mathrm{~min}$. (B). The extent of paxillin phosphorylation was measured through immunoprecipitation with anti-phospho-tyrosine antibody and Western blot analysis with anti-paxillin antibody. Data are representative of three independent experiments. 
amined the effect of PLD2 overexpression on ATPstimulated paxillin phosphorylation. As expected, overexpression of wild type PLD2 caused reduction of ATPinduced paxillin phosphorylation (Figure $3 \mathrm{~A}$ ). Overexpression of lipase-inactive mutant PLD2 could not affect on ATP-stimulated paxillin phosphorylation (Figure 3A). PLD2-mediated paxillin dephosphorylation was inhibited by Gö6976 but not by rottlerin (Figure 3B).

\section{Propranolol pretreatment inhibits ATP-stimulated Fak and paxillin phosphorylation}

PA, a product of PLD activity has been reported to be involved in various cellular responses (Frohman et al., 1999). In living cells, PA was reported to be further metabolized to DAG by PAP (Perry et al., 1993). Propranolol is a PAP-specific inhibitor (Williger et al., 1999). Pretreatment of propranolol in cells can enhance intracellular PA level by inhibition of PAP. We examined the effect of PA increment on ATP-induced Fak phosphorylation in PC12 cells with PAP inhibitor, propranolol. When propranolol was pretreated prior to ATP stimulation, ATP-induced Fak phosphorylation was reduced (Figure 4A). ATP-stimulated paxillin phosphorylation was also inhibited by propranolol (Figure 4B). This result strongly supports our notion that PLD activity-derived PA can affect on ATP-induced Fak and paxillin phosphorylation in a negative manner.

A

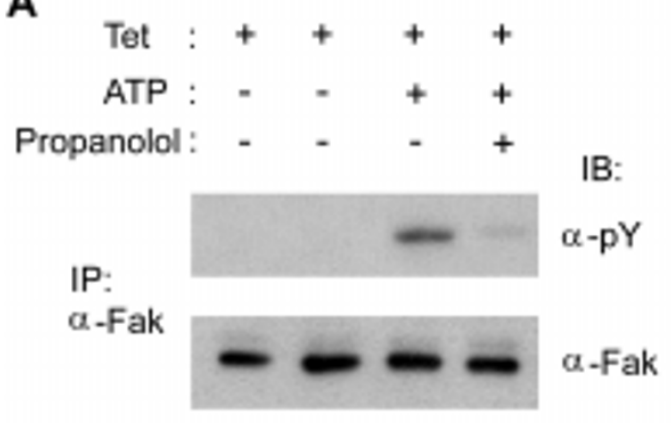

B

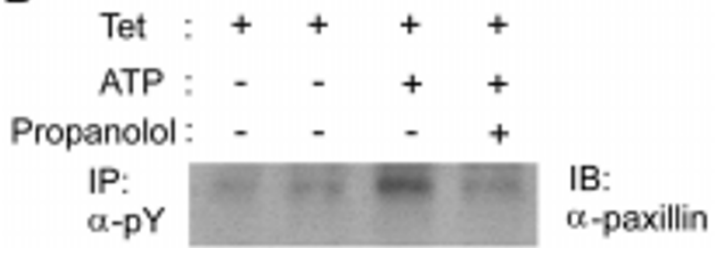

Figure 4. Effect of propranolol on ATP-stimulated Fak phosphorylation. The wild-type PLD2-inducible PC12 cells were cultured for $48 \mathrm{~h}$ in the presence of tetracycline (Tet) and then were washed twice with serum-free DMEM. Before 15 min of ATP stimulation, propranolol $(100 \mu \mathrm{M})$ was pretreated. The cells were stimulated with ATP $(500 \mu \mathrm{M})$ for 1 min and were lysed with lysis buffer. The extent of Fak (A) or paxillin phosphorylation (B) was measured as mentioned in the legends for Figure 2 or 3 . Data are representative of two experiments.

\section{Phosphatase inhibitor rescues the inhibition of ATP-} induced Fak and paxillin phosphorylation by PLD2

Our findings that overexpression of wild type PLD2 inhibits ATP-stimulated Fak and paxillin phosphorylation (Figure 2 and 3) suggest a possible involvement of certain kinases or phosphatases in the event. Previous reports demonstrated that PA regulates phosphatases, such as protein tyrosine phosphatase and serine/threonine phosphatase (Chalfant et al., 1999; Frank et al., 1999). To distinguish whether phosphatase activity is required in this process, we examined the effect of tyrosine phosphatase inhibitor (pervanadate) on the attenuation of ATP-stimulated Fak and paxillin phosphorylation by PLD2 overexpression. As shown in Figure 5A and $5 \mathrm{~B}$, pretreatment of the cells with pervanadate prior to ATP stimulation inhibited PLD2 activity-dependent Fak and paxillin dephosphorylation. These results indicate that certain tyrosine phosphatase(s) may be involved in PLD2-dependent attenuation of Fak and paxillin phosphorylation by ATP.

\section{Discussion}

PLD is expressed in neuronal cells and is activated by many kinds of agonists, and is also suggested to be an important mediator of neuronal cell functions (Glenn et al., 1998; Lee et al., 2000; Lee et al., in press). In several neuronal cell responses, activity of cytoskeletonassociated proteins such as Fak and paxillin is important (Soltoff et al., 1998; Schindelholz et al., 2000). Although many ligands that stimulate Fak and paxillin phosphorylation also stimulate PLD activity, little is known about the role of PLD on the regulation of Fak and paxillin activity. In this study, we addressed a possible negative role of PLD2 on ATP-stimulated Fak and paxillin activation.

We showed that overexpression of PLD2 inhibited ATP-induced Fak and paxillin phosphorylation (Figure 2 and 3). We also demonstrated that this event is PLD2 lipase activity-dependent by showing 1) overexpression of wild type but not lipase-inactive mutant PLD2 elicited ATP-stimulated Fak and paxillin dephosphorylation, 2) increment of PA with propranolol pretreatment caused ATP-induced Fak and paxillin dephosphorylation (Figure 4). In the experiments to reveal the mechanisms involved in this event, we found that pervanadate restored PLD2 activity-mediated Fak and paxillin dephosphorylation (Figure 5). These results suggest a possible involvement of certain phosphatases on the dephosphorylation of Fak. Several previous reports have suggested some candidate target proteins for PA (Tomic et al., 1995; Zhao et al., 1993). For instance, activity of PTP1C (also referred to as SH-PTP1, HCP, SHP) was known to be stimulated $>1000$-fold by anionic phospho- 
A

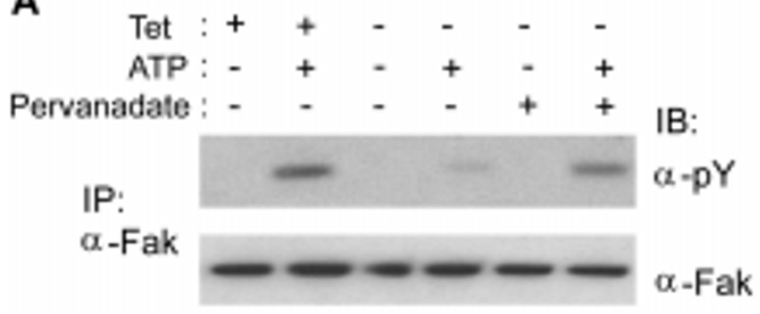

B

$\begin{array}{lllllll}\text { Tet }: & + & + & - & - & - & - \\ \text { ATP : } & - & + & - & + & - & + \\ \text { Pervanadate : } & - & - & - & + & + \\ \text { IP: } & & & & & & \text { IB: } \\ \alpha \text { - } \text { PY } & & & & & & \alpha \text {-paxillin }\end{array}$

Figure 5. Effect of pervanadate on PLD2-mediated Fak and paxillin dephosphorylation by ATP stimulation. The wild-type PLD2-inducible PC12 cells were cultured for $48 \mathrm{~h}$ in the presence or absence of tetracycline (Tet) and then were washed twice with serum-free DMEM. Before $15 \mathrm{~min}$ of ATP stimulation, pervanadate $(10 \mu \mathrm{M})$ was pretreated. The cells were stimulated with ATP $(500 \mu \mathrm{M})$ for $1 \mathrm{~min}$ and were lysed with lysis buffer. The extent of Fak (A) or paxillin phosphorylation (B) was measured as mentioned in the legends for Figure 2 or 3 . Data are representative of three experiments.

lipids such as PA when myelin basic protein or mitogenactivated protein kinase is used as substrate (Zhao et al., 1993). On the PTP1C activation by PA, direct interaction between the lipid and PTP1C is demonstrated to cause a conformational change of the phosphatases that facilitates proteolytic degradation (Zhao et al., 1993). We also checked the effect of overexpression of PLD2 on PTP1C activity by band shift assay with Western blot analysis. In our experiments, we could not detect any significant effect of PLD2 activity on PTP1C activity in PC12 cells (data not shown). So we think that other phosphatase(s) but not PTP1C play a role in PLD2-mediated Fak dephosphorylation.

In our previous report, we demonstrated that PLD2 overexpression inhibited ATP-stimulated mitogenic activity via ERK dephosphorylation (Lee et al., in press). Many agonists including ATP have been known to activate ERK, and this ERK activation is mediated by Fak or Pyk2 (Soltoff et al., 1998). Since we found that PLD2 activity inhibited Fak kinase, an upstream molecule for ERK activating signaling, it looks like possible that PLD2 activity attenuates ERK activity via Fak dephosphorylation and certain phosphatase(s) are involved in this event. Recently a paper demonstrated that PA produced from PLD1 activation facilitated ERK phosphorylation by lysophosphatidic acid in GP + envAM12 cell, a derivative of NIH 3T3 cell (Hong et al., 2001). It indicates that PA can modulate ERK phosphorylation positively or negatively by different agonists in different cell types. Studies on whether two isozymes of PLD have different roles on PA-mediated ERK modulation are need. Fak activation can modulate not only ERK but also paxillin activation (Soltoff et al., 1998; Turner, 2000). Our result that PLD2 activity inhibits paxillin phosphorylation indicates a possible negative role of PLD2 on cytoskeleton dynamics resulting in cellular morphogenesis.

\section{Acknowledgements}

This work was supported in part by the programs of National Research Laboratory of Ministry of Science and Technology, the Center for Cell Signaling Research and the Brain Korea 21 Project for Korea.

\section{References}

Chalfant CE, Kishikawa K, Mumby MC, Kamibayashi C, Bielawska A, Hannun YA. Long chain ceramides activate protein phosphatase-1 and protein phosphatase-2A. Activation is stereospecific and regulated by phosphatidic acid. $\mathrm{J}$ Biol Chem 1999;274:20313-17

Communi D, Janssens R, Suarez-Huerta N, Robaye B, Boeynaems JM. Advances in signalling by extracellular nucleotides; the role and transduction mechanisms of P2Y receptors. Cell Signal 2000;12:351-60

Di lorio P, Ballerini P, Caciagli F, Ciccarelli R. Purinoceptormediated modulation of purine and neurotransmitter release from nervous tissue. Pharmacol Res 1998;37:169-78

Djerdjouri B, Lenoir M, Giroud JP, Perianin A. Contribution of mitogen-activated protein kinase to stimulation of phospholipase $D$ by the chemotactic peptide fMet-Leu-Phe in human neutrophils. Biochem Biophys Res Commun 1999;264:371-75

Exton JH. Phospholipase D. Ann NY Acad Sci 2000;905:6168

Frank C, Keilhack H, Opitz F, Zschornig O, Bohmer FD. Binding of phosphatidic acid to the protein-tyrosine phosphatase SHP-1 as a basis for activity modulation. Biochemistry 1999;38:11993-2002

Frohman MA, Sung TC, Morris AJ. Mammalian phospholipase D structure and regulation. Biochim Biophys Acta 1999;1439:175-86

Glenn DE, Thomas GM, O'Sullivan AJ, Burgoyne RD. Examination of the role of ADP-ribosylation factor and phospholipase $D$ activation in regulated exocytosis in chromaffin and PC12 cells. J Neurochem 1998;71:2023-33

Hong JH, Oh SO, Lee M, Kim YR, Kim DU, Hur GM, Lee JH, Lim K, Hwang BD, Park SK. Enhancement of lysophosphatidic acid-induced ERK phosphorylation by phospholipase D1 via the formation of phosphatidic acid. Biochem Biophys Res Commun 2001;281:1337-42

Kim Y, Kim JE, Lee SD, Lee TG, Kim JH, Park JB, Han JM, Jang SK, Suh PG, Ryu SH. Phospholipase D1 is located and activated by protein kinase $\mathrm{C}$ alpha in the plasma membrane 
in $3 Y 1$ fibroblast cell. Biochim Biophys Acta 1999;1436:319-30

Kozawa O, Blume-Jensen P, Heldin $\mathrm{CH}$, Ronnstrand L. Involvement of phosphatidylinositol $3^{\prime}$-kinase in stem-cellfactor-induced phospholipase $D$ activation and arachidonic acid release. Eur J Biochem 1997;248:149-55

Lee CS, Bae YS, Lee SD, Suh PG, Ryu SH. ATP-induced mitogenesis is modulated by phospholipase D2 through extracellular signal regulated protein kinase dephosphorylation in rat pheochromocytoma PC12 cells. Neurosci Lett In press

Lee SD, Lee BD, Han JM, Kim JH, Kim Y, Suh PG, Ryu SH. Phospholipase D2 activity suppresses hydrogen peroxideinduced apoptosis in PC12 cells. J Neurochem 2000;75: 1053-59

Liscovitch M, Czarny M, Fiucci G, Tang X. Phospholipase D: molecular and cell biology of a novel gene family. Biochem $\mathrm{J}$ 2000;345:401-15

Neary JT, Rathbone MP, Cattabeni F, Abbracchio MP, Burnstock G. Trophic actions of extracellular nucleotides and nucleosides on glial and neuronal cells. Trends Neurosci 1996;19:13-18

Perry DK, Stevens VL, Widlanski TS, Lambeth JD. A novel ecto-phosphatidic acid phosphohydrolase activity mediates activation of neutrophil superoxide generation by exogenous phosphatidic acid. J Biol Chem 268: 1993;25302-10
Schindelholz B, Reber BF. L-type $\mathrm{Ca}^{2+}$ channels and purinergic P2X2 cation channels participate in calcium-tyrosine kinase-mediated PC12 growth cone arrest. Eur J Neurosci 2000;12:194-204

Soltoff SP, Avraham H, Avraham S, Cantley LC. Activation of P2Y2 receptors by UTP and ATP stimulates mitogen-activated kinase activity through a pathway that involves related adhesion focal tyrosine kinase and protein kinase C. J Biol Chem 1998;273:2653-60

Tomic S, Greiser U, Lammers R, Kharitonenkov A, Imyanitov $\mathrm{E}$, Ullrich A, Bohmer FD. Association of $\mathrm{SH} 2$ domain protein tyrosine phosphatases with the epidermal growth factor receptor in human tumor cells. Phosphatidic acid activates receptor dephosphorylation by PTP1C. J Biol Chem 1995;270:2127784

Turner CE. Paxillin and focal adhesion signalling. Nat Cell Biol 2000;2:E231-36

Williger BT, Ho WT, Exton JH. Phospholipase D mediates matrix metalloproteinase-9 secretion in phorbol ester-stimulated human fibrosarcoma cells. J Biol Chem 1999;274:73538

Zhao Z, Shen SH, Fischer EH. Stimulation by phospholipids of a protein-tyrosine-phosphatase containing two src homology 2 domains. Proc Natl Acad Sci U. S. A. 1993;90:4251-55 